\title{
Crystal structure of DRIK1, a stress- responsive receptor-like pseudokinase, reveals the molecular basis for the absence of ATP binding
}

\author{
Bruno Aquino ${ }^{1}$, Viviane C. H. da Silva ${ }^{1,2}$, Katlin B. Massirer ${ }^{1,3}$ and Paulo Arruda ${ }^{1,2,3,4^{*}}$ (D)
}

\begin{abstract}
Background: Plants reprogram metabolism and development to rapidly adapt to biotic and abiotic stress. Protein kinases play a significant role in this process by phosphorylating protein substrates that activate or inactivate signaling cascades that regulate cellular and metabolic adaptations. Despite their importance in plant biology, a notably small fraction of the plant kinomes has been studied to date.

Results: In this report, we describe ZmDRIK1, a stress-responsive receptor-like pseudokinase whose expression is downregulated under water restriction. We show the structural features and molecular basis of the absence of ATP binding exhibited by ZmDRIK1. The ZmDRIK1 kinase domain lacks conserved amino acids that are essential for phosphorylation activity. The crystal structure of the ZmDRIK1 kinase domain revealed the presence of a spine formed by the side chain of the triad Leu ${ }^{240}, \mathrm{Ty}^{363}$, and $\mathrm{Leu}^{375}$ that occludes the ATP binding pocket. Although ZmDRIK1 is unable to bind nucleotides, it does bind the small molecule ENMD-2076 which, in a cocrystal structure, revealed the potential to serve as a ZmDRIK1 inhibitor.

Conclusion: ZmDRIK1 is a novel receptor-like pseudokinase responsive to biotic and abiotic stress. The absence of ATP binding and consequently, the absence of phosphorylation activity, was proven by the crystal structure of the apo form of the protein kinase domain. The expression profiling of the gene encoding ZmDRIK1 suggests this kinase may play a role in downregulating the expression of stress responsive genes that are not necessary under normal conditions. Under biotic and abiotic stress, ZmDRIK1 is down-regulated to release the expression of these stress-responsive genes.
\end{abstract}

Keywords: Protein kinase, Pseudokinase, Drought stress, Biotic stress, Abiotic stress

\section{Background}

Plants are sessile organisms that must constantly reprogram their metabolisms to adapt to environmental changes, such as high/low temperature, high/low light

\footnotetext{
* Correspondence: parruda@unicamp.br

'Structural Genomics Consortium, Universidade Estadual de Campinas UNICAMP, Campinas, SP 13083-886, Brazil

${ }^{2}$ Joint Research Center for Genomic Applied to Climate Change (UMIP-GenClima), Campinas, SP 13083-875, Brazil

Full list of author information is available at the end of the article
}

intensity, and water restriction. When stress is prolonged for a few days, plant growth and development are affected, leading to yield loss. The responses to those environmental changes are coordinated at transcriptional, translational and posttranslational levels. One of the significant posttranslational modifications occurring is the protein phosphorylation of specific substrates, which is exerted by protein kinases whose expanded families in plants may have significantly contributed to stress

C C The Author(s). 2020 Open Access This article is licensed under a Creative Commons Attribution 4.0 International License, which permits use, sharing, adaptation, distribution and reproduction in any medium or format, as long as you give appropriate credit to the original author(s) and the source, provide a link to the Creative Commons licence, and indicate if changes were made. The images or other third party material in this article are included in the article's Creative Commons licence, unless indicated otherwise in a credit line to the material. If material is not included in the article's Creative Commons licence and your intended use is not permitted by statutory regulation or exceeds the permitted use, you will need to obtain permission directly from the copyright holder. To view a copy of this licence, visit http://creativecommons.org/licenses/by/4.0/ The Creative Commons Public Domain Dedication waiver (http://creativecommons.org/publicdomain/zero/1.0/) applies to the data made available in this article, unless otherwise stated in a credit line to the data. 
adaptation [1, 2]. One class of protein kinases, the receptor-like kinases (RLKs), play significant roles in the stress response in plants. Typically, RLKs have an extracellular domain that generally binds ligands to activate the intracellular kinase domains and consequently modulates signaling pathways by transferring the gammaphosphate group of ATP to a protein substrate [3, 4]. RLKs comprise the largest group of plant kinases belonging to a distinct family RLK/Pelle, mostly having a leucine-rich repeat (LRR) corresponding to RLK/Pelle LRR subfamilies. The RLK/Pelle family is comprised of more than 600 members out of 1000 kinases in Arabidopsis, more than 1100 members out of 1400 kinases in rice and approximately 760 members out of 1241 kinases in maize [5-7]. Despite the importance and representativeness of RLKs in plants, only a few RLKs have wellknown functions [8-10], and fewer of them have their specific ligands identified. Those ligands include endogenous proteins, sulfonated peptides, steroid hormones and pathogen-derived peptide elicitors $[4,11]$.

The known RLKs have been shown to participate in developmental regulation, disease resistance, and stress tolerance in plants. The growth and development can be exemplified by LRR-RLKs that sense growth-promoting brassinosteroids and to regulate cell elongation and division, such as Brassinosteroid Insensitive 1 (BRI1), or sense peptide hormones to regulate root development such as Root Meristem Growth Factor Receptor 1-3 (RGFR1-3), stem cell maintenance in shoot and root such as Clavata 1 (CLV1), Barely Any Meristem 1-3 (BAM1-3), Receptor-like Protein Kinase 2 (RPK2), abscission and cell separation (HAESA and HAESA-LIKE 2 (HSL2), and stomatal patterning (ERECTA and ERECTA-LIKE 1 (ERL1) [4, 12]. Other LRR-RLKs, such as somatic embryogenesis receptor-like kinases (SERKs) receptor family, including BRI1-Associated Receptor Kinase 1 (BAK1), are involved in a wide spectrum of biological processes, including plant development and disease resistance [13]. Additionally, the RLKs involved in the plant immune system such as Flagellin-Sensitive 2 (FLS2) that senses bacterial flagellin [14], rice Xa-21 conferring resistance to bacterial pathogens [15], and NSP-Interacting Kinase 1 (NIK1) as a defense receptor of geminivirus and begomovirus [16]. The abiotic stress responses driven by RLKs include the abscisic acid (ABA) response, calcium signaling and antioxidant defense against drought, salt, cold, toxic metals/metalloids, ozone and UV-B radiation, and other stresses [2]. Drought stress is an important cause of productivity loss and few RLKs have already being identified as drought sensing receptors. One example is Floral Organ Number 1 (FON1) an ABA sensitivity rice LRR-RLK has been shown to be associated with increased drought tolerance [17]. Other examples are Leaf Panicle 2 (LP2) in rice and
Leaf Rust 10 Disease-Resistance Locus Receptor-Like Protein Kinase-Like 1.2 (LRK10L1.2) in wheat that has been associated with drought stress response via ABAmediated signaling $[18,19]$. In an ABA-independent pathway, Stress-Induced Protein Kinase 1 (OsSIK1) [20] and Stress-Induced Protein Kinase 2 (OsSIK2) [21] has been shown to control water loss by stomatal development regulation and upregulation of genes related to detoxification of reactive oxygen species. Another example is BRI1-Like Receptor Kinase 3 (BRL3 recently described as conferring drought tolerance [22].

Approximately $10-20 \%$ of eukaryotic kinome members lack phosphorylation activity and are called pseudokinases $[10,23]$. In general, those kinases lack essential amino acids for catalysis and thus are not able to phosphorylate any substrate. Regardless of that deficiency, pseudokinases have essential roles in the cell metabolism, acting as kinase scaffolds or as allosteric modulators of signaling components [24-28]. Pseudokinases can act as auxiliary proteins perturbing the conformation of the protein partner by allosteric regulation or acting as a scaffold recruiting a catalytically active kinase to trigger protein activation via phosphorylation. For example, the Arabidopsis pseudokinases Bak1-Interacting ReceptorLike Kinase2 (BIR2), Coryne (CRN) and Receptor Dead Kinase 1 mediate immune responses, stem cell homeostasis, and plant responses to ABA during seedling development, respectively [29-33]. Another example is the receptor-like pseudokinase Guard Cell Hydrogen Peroxide-Resistant 1 (GHR1), which acts as a scaffold interacting with Slow Anion Channel 1 (SLAC1) and with Calcium-Dependent Protein Kinase 3 (CPK3) to induce stomatal closure [26]. In maize, the RLK Pangloss 2 (PAN2), a pseudokinase homologous to GHR1, promotes the polarization of subsidiary mother cell division towards the adjacent guard mother cell during stomatal development [34, 35]. These catalytically inactive kinases retain a high degree of sequence conservation in the kinase domain, suggesting that kinase domain fold and structure are required for signaling activity, while their different biological functions are driven by divergences in the extracellular domains [12, 36, 37]. Nevertheless, it has recently been shown that the specificity of some pseudokinases can also be determined by their intracellular kinase domains, while the ectodomains allow their binding to other transmembrane proteins $[4,26,38,39]$.

Despite the importance of pseudokinases, they have not been well-characterized from the structural biology perspective in plants, which has contributed to a significant knowledge gap to elucidate their functional mechanisms. In this study, we identified a maize RLK that is regulated by water availability from a transcriptional profiling data set [40]. We named this RLK DROUGHT RESPONSIVE INACTIVE KINASE 1, or ZmDRIK1. The 
crystal structure of the ZmDRIK1 kinase domain was resolved at the apo form and as a cocrystal structure with a high-affinity small molecule. The mechanism of the absence of ATP binding was elucidated, as well as the transcriptional profiling under water availability characterized. Taken together, the results may help to elucidate the molecular mechanism of the drought stress response and thus help to generate maize lines that are more tolerant to drought stress.

\section{Results}

DRIK1 is conserved among evolutionarily distant plants Inspections into the Genevestigator experimental database [41] allowed the identification of $Z m D R I K 1$, a receptor kinase that is downregulated under drought stress and upregulated after rewatering in both droughttolerant and sensitive maize lines, Han21 and Ye478, respectively (Additional file 1: Figure S1). Analysis of the amino acid sequence at the kinase domain revealed alterations in residues essential for ATP binding and kinase activity, suggesting that the protein could be a pseudokinase. We subsequently investigated if the gene encoding DRIK1 is conserved in plants. DRIK1 resembling sequences were retrieved from public databases and inspected for their phylogenetic distribution. DRIK1 homologs were identified in sorghum, rice, wheat, Arabidopsis and soybean (Fig. 1a). Since kinase domains are highly conserved even among kinases from different kingdoms, we analyzed the intron/exon of DRIK1 gene structures from maize, sorghum, rice and Arabidopsis (Fig. 1b). In maize and sorghum, the closest related analyzed plants, the gene structure is composed of six exons, each having a similar length among the two species. The rice DRIK1 gene has one small extra exon that appears to be generated by the introduction of an intron in the third exon compared with the DRIK1 gene from

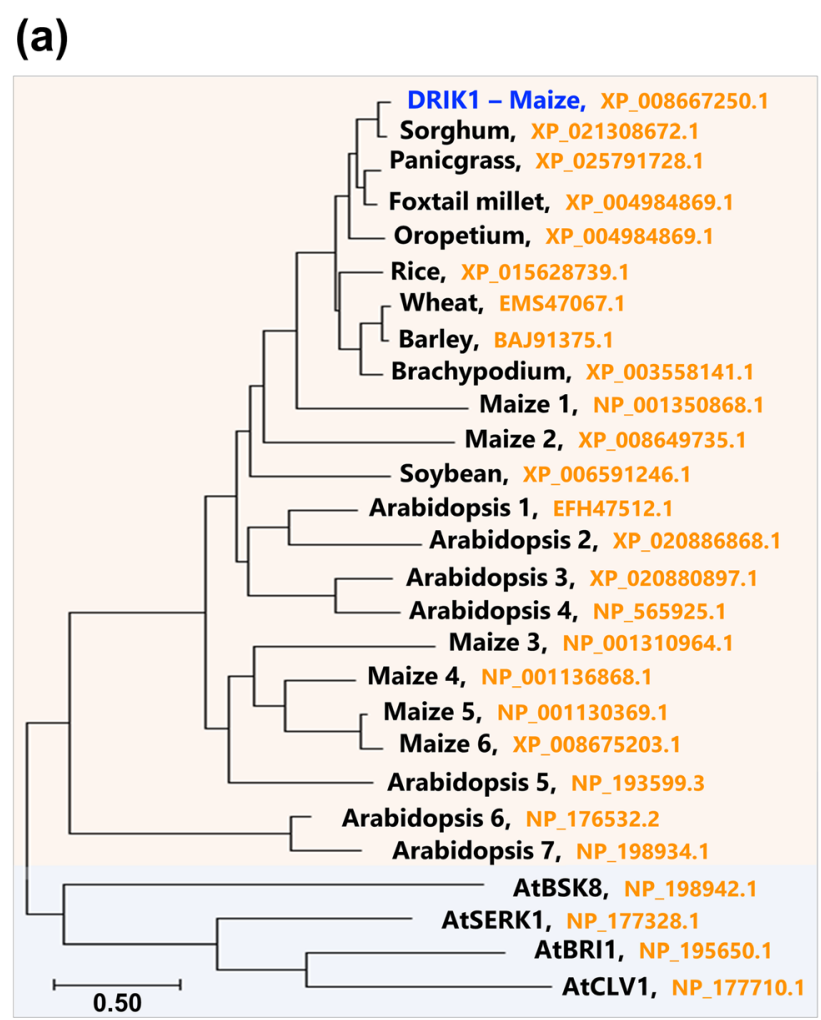

(b) transmembrane kinase domain

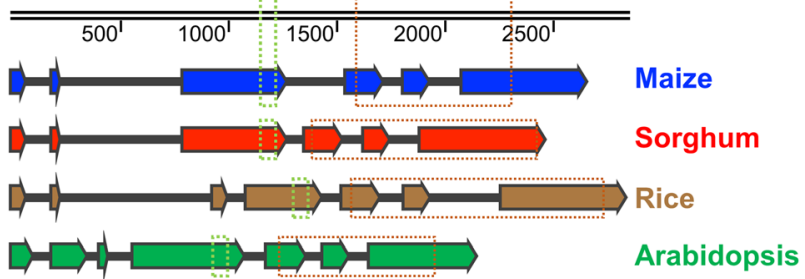

(c)

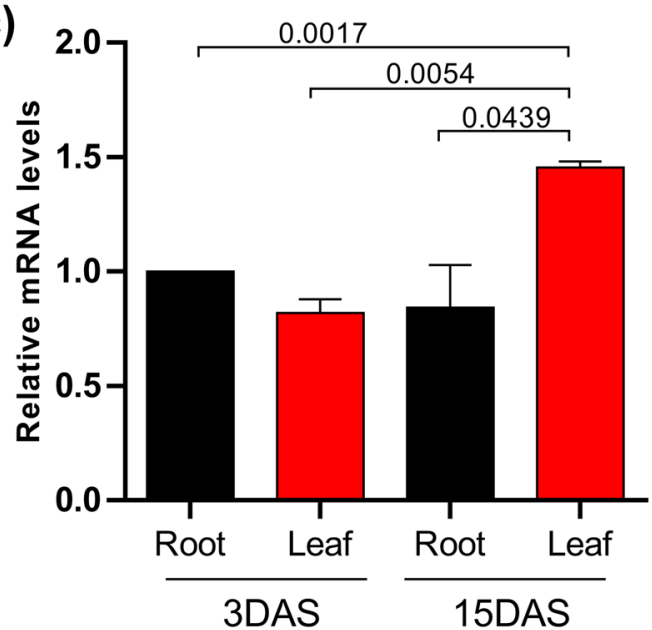

Fig. 1 Maize DRIK1 is a conserved RLK expressed in roots and leaves. a Phylogenetic analysis of ZmDRIK1. Amino acid sequences of representative proteins of the subfamily LRR-VI-2 from several species were aligned, and a phylogenic tree was constructed using the out-groups AtSERK1, AtBRI1, AtCLV1 (catalytically active kinases), and AtBSK8 (catalytically inactive kinase). b Intron/exon structure of the ZmDRIK1 gene compared with closely related genes from maize, sorghum, rice and Arabidopsis. Exons are colored arrows, and introns are black lines. The transmembrane domain (green dotted line) and the kinase domain (red dotted line) corresponding regions are shown. Numbers indicate nucleotide positions along the gene sequence. c ZmDRIK1 relative mRNA content in roots and leaves at 3 and 15 days after sowing (DAS), as determined by qRT-PCR. $\beta$-tubulin was used to normalize samples. At alpha 0.05 level, the relative mRNA level of ZmDRIK1 in leaves at 15 DAS was significantly greater than that level in roots, as well as greater than the mRNA level in leaves and roots from younger seedling (3 DAS). The $p$-values of Student's t test between tissues or age from seedlings, are indicated above the comparative lines in the figure. Error bars indicate standard deviation between three biological replicates 
maize. The Arabidopsis DRIK1 is shorter, but the length of the exons is conserved and more similar to that of rice.

DRIK1 belongs to the LRR VI-2 kinase subfamily, and inspections of this group revealed that the maize DRIK1 gene is not duplicated (Additional file 2: Figure S2a). The DRIK1 gene sequence showed low identity when aligned with other maize LRR VI-2 subfamily members, although the region encoding the corresponding kinase domain is highly conserved (Additional file 2: Figure S2b and S2c). In general, plant gene families arose from duplication events during evolution and are paralogous generally having redundant functions. The fact that the DRIK1 gene is present in a single copy in maize may facilitate further functional analysis to determine its role in plant metabolism, especially the molecular mechanism associated with drought stress response.

The gene expression profile of roots and leaves during the early stages of plant development shows that DRIK1 expression in the leaves is $50 \%$ higher in the 15- as compared to that of 3-day-after-sowing (DAS). This result suggests a developmental role of DRIK1 as plant growth and leaf expansion (Fig. 1c).

\section{ZmDRIK1 is regulated by biotic and abiotic stress}

Investigations of the RNAseq data from the Genevestigator database revealed that the ZmDRIK1 gene is downregulated in response to biotic and abiotic stress (Additional file 3: Figure S3). ZmDRIK1 gene expression is downregulated after infection for $48 \mathrm{~h}$ with Glomerella graminicola and Cercospora zeina fungi. The gene is also downregulated when plants are exposed to high and low temperatures, submergence and drought stress. On the other hand, the gene was upregulated during germination (Additional file 4: Figure S4). However, we must consider these data with caution because they were generated in high-throughput modes that were not specifically validated for $Z m D R I K 1$.

To experimentally validate the ZmDRIK1 expression pattern, we analyzed the mRNA level of ZmDRIK1 in leaves of plants subjected to drought stress (Fig. 2). Maize B73 plants growing in pots with soil for 8 days had their watering restricted for 9, 12 and 14 days, after which they were rewatered, and leaf samples of both drought-stressed and rewatered plants were analyzed for $Z m D R I K 1$ mRNA level. The ZmDRIK1 mRNA level was downregulated soon after 9 days of water restriction and was restored after $24 \mathrm{~h}$ of rewatering (Fig. 2).

\section{ZmDRIK1 is a receptor-like pseudokinase}

$Z m D R I K 1$ is a transmembrane protein with an extracellular domain harboring a low-complexity region and a kinase domain in the intracellular portion of the protein. In general, active kinases have amino acid residues at

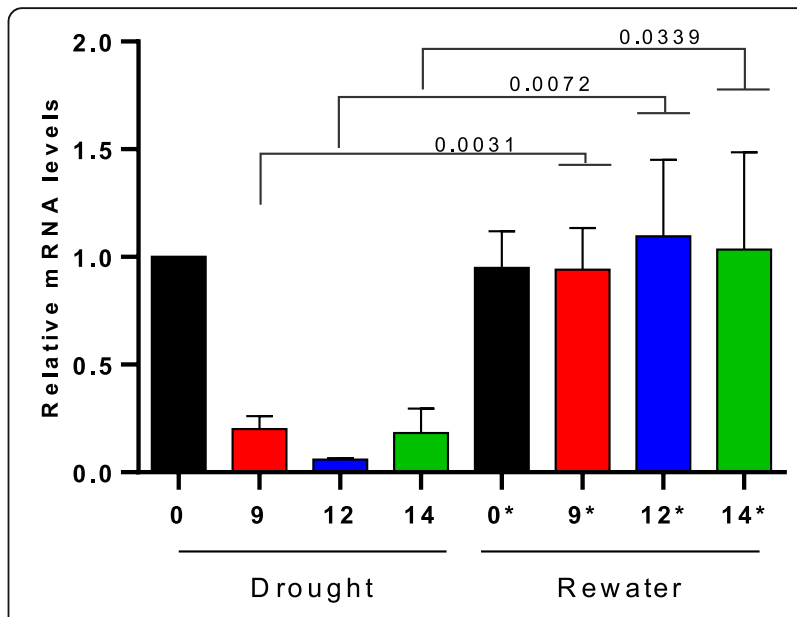

Fig. $2 \mathrm{ZmDRIK1}$ expression is downregulated under drought stress. B73 maize plants were grown in pots with soil for 13,10 or 8 days after which watering was stopped for 9, 12 or 14 days (days of stress), respectively. Half of the stress-treated plants were sampled and immediately immersed in liquid nitrogen and stored at $-80^{\circ} \mathrm{C}$. The other half of the stress-treated plants (marked with ${ }^{*}$ ), were rewatered for $24 \mathrm{~h}$ and then sampled. Results are average \pm standard deviation (three biological replicates) of relative mRNA content of ZmDRIK1 in leaves of maize plants, submitted to drought-stress and rewatering treatments. The gene EIF4a was used for expression normalization. At alpha 0.05 level, the relative mRNA level of ZmDRIK1 in drought-stressed leaves was significatively lower than its level in leaves of rewatered plants, with the same period of treatment. The $p$-values of Student's $t$ test between treatments are indicated above the comparative lines in the figure

conserved positions that are essential for kinase activity. To confirm that $Z m$ DRIK1 is an inactive kinase, we aligned DRIK1 from different species and with active (BRI1; CLV1; IRAK4; PKA) and inactive (BSK8; BIR2) kinases (Fig. 3a). DRIK1 from maize, sorghum, rice, and Arabidopsis have minimal amino acid sequence variation among them. In the P-loop, a conserved sequence Gly$\mathrm{X}$-Gly-X-X-Gly is observed in active kinases [42], while in maize, sorghum, and rice, the second and third glycines are substituted by Thr and Cys, respectively. As these changes occurred for small amino acids, they might not influence ATP binding or even the catalytic activity of DRIK1. Another important feature of active kinases is the conserved Asp-Phe-Gly motif, where Asp is important to coordinate the $\mathrm{Mg}^{2+}$ ion with ATP. In DRIK1, the Asp-Phe-Gly motif is changed to Asp-LeuGlu, and the conservation of the amino acid Asp suggests that this feature is not compromised. On the other hand, the Asp residue from the His-Arg-Asp-X-Lys-X$\mathrm{X}$-Asn motif of the catalytic loop is essential to accept the hydrogen from the hydroxyl group being phosphorylated [43]. In DRIK1, this amino acid is substituted by the polar uncharged amino acid Asn, suggesting that phosphorylation could not happen. One of the most important kinase catalytic amino acids is the Lys in the 
(a)
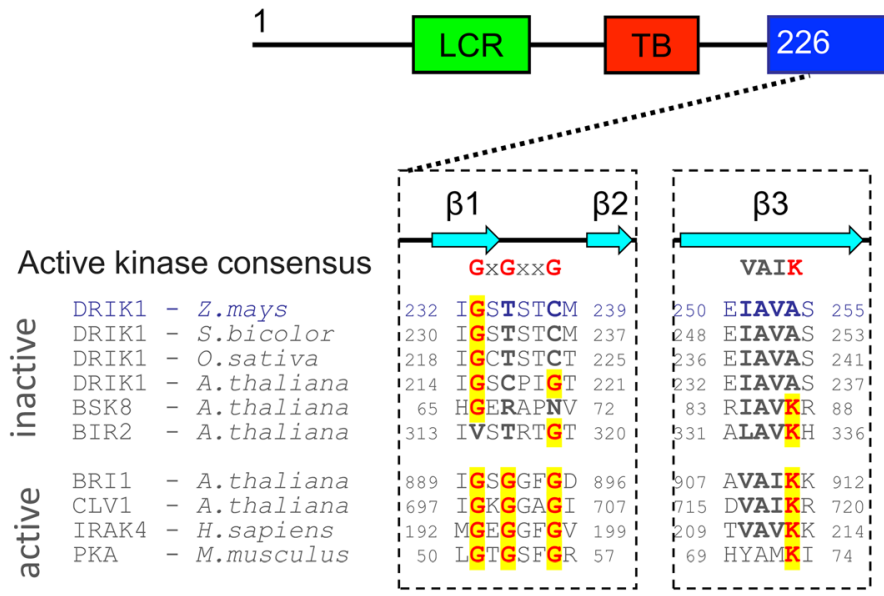

\section{Kinase domain}

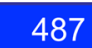

514

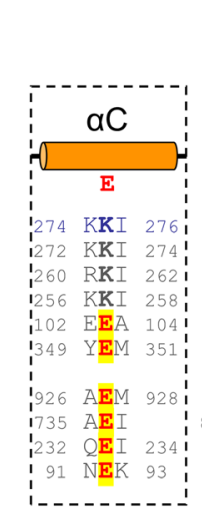

GTP

Time (s)

(c)

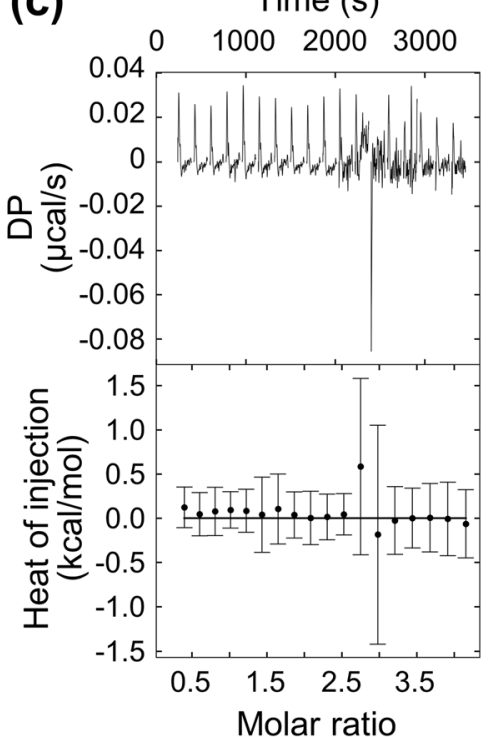

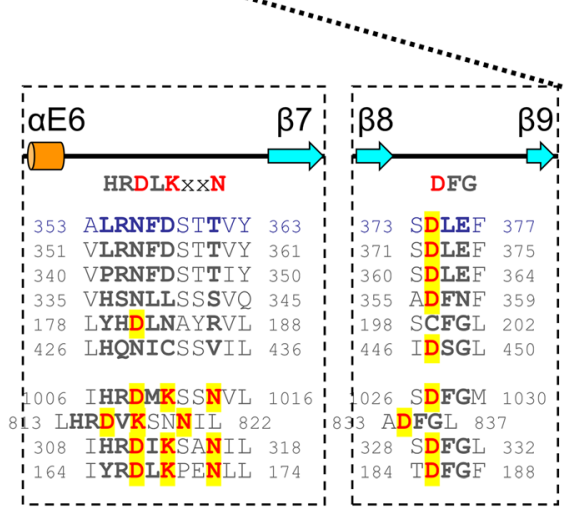

AMP-PNP

Time (s)

$0 \quad 1000 \quad 2000 \quad 3000$

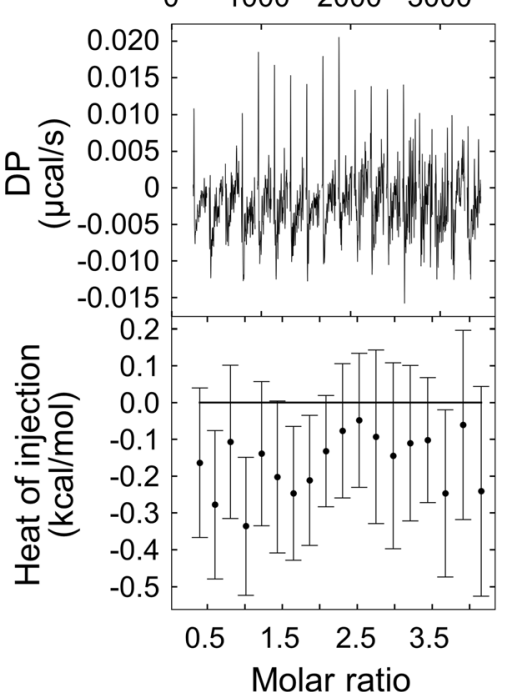

Fig. 3 DRIK1 is a pseudokinase that is unable to bind nucleotides. a $Z m D R I K 1$ protein domain structure and multiple amino acid sequence alignment of ZmDRIK1 with a set of active and inactive RLK/Pelle-LRRs. The schematic ZmDRIK1 domain structure shows the position of the low complexity region (green), the transmembrane domain (red) and the kinase domain (blue). Numbers indicate amino acid positions along the protein sequence. The multiple amino acid sequence alignment shows the core of the kinase domains of: DRIK1 from maize, sorghum, rice and Arabidopsis; BIR2, BRI1 and BSK8 and CLV1 from Arabidopsis; IRAK4 from Homo sapiens; PKA from Mus musculus. Conserved residues, essential for kinase activity, are marked in red. Highlighted in yellow are the conserved residues representing the consensus kinase sequence. Secondary structures ( $\beta$-strands in light blue arrow; a-helix in orange cylinders) are named according to the PKA structure, except aE6, which in PKA is a $\beta$ -

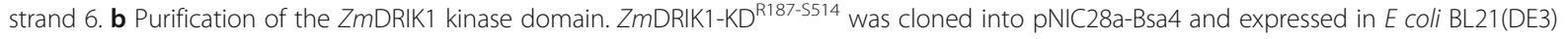
pRARE. Lanes are TL, total lysate; S, supernatant; FT, flow through; W, washed out; E, eluted fraction, $T+$, TEV protease treated. PP, gel filtration purified ZmDRIK1-KD R187-S514. MW, molecular weight of protein standards in $\mathrm{KDa}$. The original SDS-PAGE gels can be viewed from Additional file 9: Figures S6-S7. c ZmDRIK1-KD ${ }^{\text {R187-S514 }}$ binding assays for GTP and AMP-PNP as analyzed by ITC

Val-Ala-Ile-Lys motif. In DRIK1, from all species analyzed, this amino acid is substituted by Ala. In addition, the amino acid Glu from the C-helix is substituted by Lys. These two amino acids (Lys from Val-Ala-Ile-Lys motif and Glu from C-helix) form a salt bridge that is important for interacting with ATP in the ATP-binding pocket and promoting phosphorylation. Therefore, these amino acid changes suggest that even if $Z m D R I K 1$ was able to bind ATP, the absence of catalytic amino acids strengthens its pseudokinase nature.

Several pseudokinases, despite being unable to phosphorylate other proteins, can bind ATP [44-46] and change conformation to interact with other proteins and regulate metabolic pathways $[47,48]$. We investigated 
whether ZmDRIK1-KD could bind nucleotides. The purified recombinant $Z m D R I K 1-K D^{\text {R187-S514 }}$ (Fig. 3b) did not bind GTP or the ATP analog AMP-PNP (Fig. 3c).

\section{Triad Leu240, Tyr363 and Leu375 impairs nucleotide binding at the ATP pocket}

To understand the lack of nucleotide interaction with the ZmDRIK1-KD ATP pocket at the molecular level, we solved the ZmDRIK1-KD crystal structure at $1.7 \AA$. The crystal structure of the protein spanning amino acids $\mathrm{Leu}^{209}$ to $\mathrm{Pro}^{491}$ revealed a canonical kinase domain structure with an $\mathrm{N}$-terminus lobe, mainly formed by $\beta$ sheets, and a C-terminus lobe, mainly formed by $\alpha$-helix, that are connected by a hinge (Fig. 4a). The protein portion spanning amino acids 380 to 394 of the activation loop and amino acids 419 to 425 of the loop formed between F and G-helix in the C-terminus lobe were not observed in the density map, probably because of the flexibility of these regions.

The ATP binding pocket is structured as a cavity exposed to the solvent (Fig. 4b and e). However, the side chain of the Leu ${ }^{240}, \mathrm{Tyr}^{363}$ and $\mathrm{Leu}^{375}$ amino acids triad occupies the ATP binding site, suggesting that this

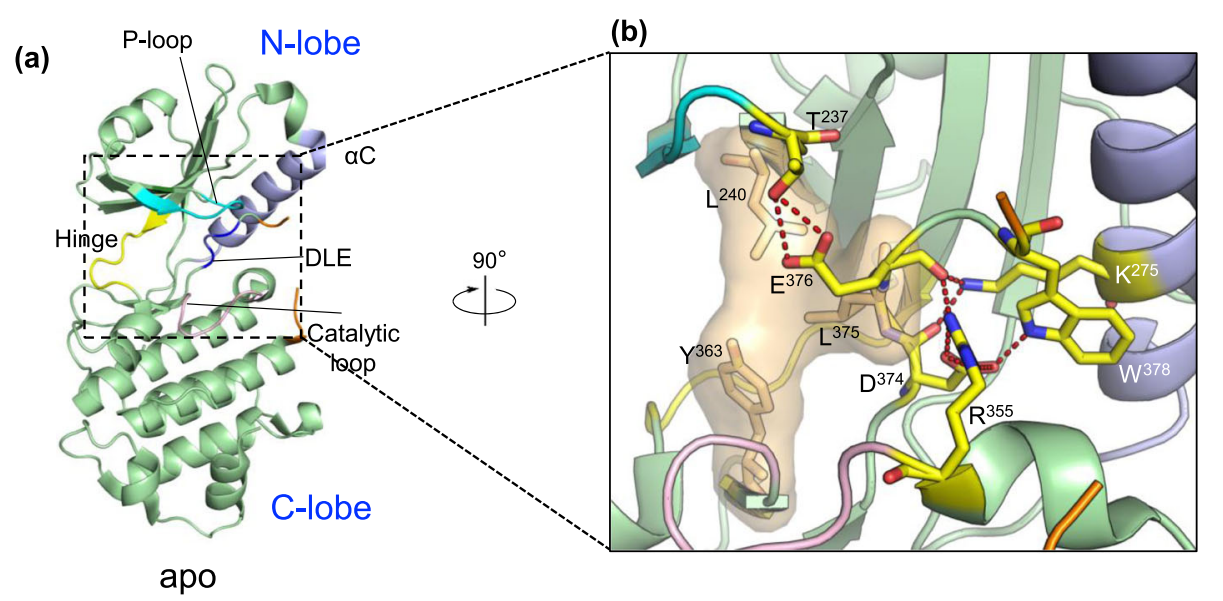

(c) DRIK1apo
(PDB:6CPY)

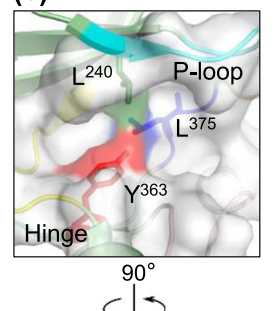

(f)

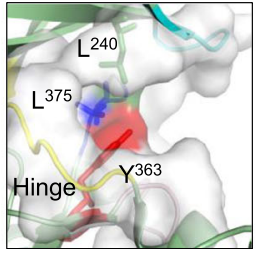

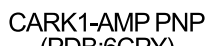

(d)

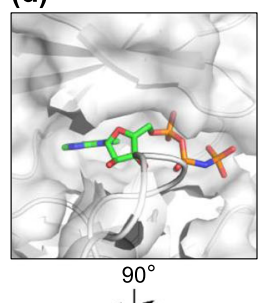
(PDB:6CPY)

DRIK1apo (PDB:6CPY)

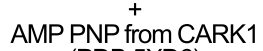

(e) (PDB:5XD6)

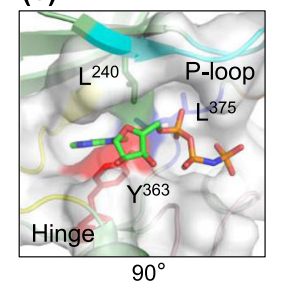

(h)
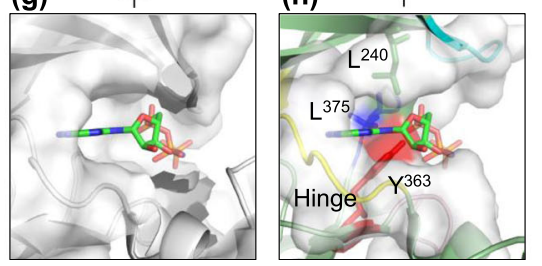

Fig. 4 Crystal structure of ZmDRIK1 apo form. a Cartoon representation of the ZmDRIK1-KD structure in the apo form. Structure features: glycinerich (P-loop - cyan; hinge region - yellow; catalytic loop -pink; DLE (more commonly DFG) motif - blue; activation segment - orange; C-helix purple. Other protein regions are in green. $\mathbf{b}$ Closer look at the ATP binding pocket. Amino acids important for ATP binding and pocket stabilization are shown as stick (carbon in yellow; oxygen in red; nitrogen in blue) and the interaction between them in red dashed lines. Surface of amino acids Leu ${ }^{240}$, Tyr $^{363}$ and Leu ${ }^{375}$ are shown in light orange. (c and $\mathbf{f}$ ) Catalytic pocket of apo ZmDRIK1-KD (PDB: 6CPY). Leu ${ }^{240} ;$ Tyr $^{363}$ and Leu $^{375}$ are shown as sticks, and the surfaces of these amino acids are colored green, blue and red, respectively. (d and $\mathbf{g}$ ) Catalytic pocket of CARK1 cocrystallized with AMP-PNP (PDB: 5XD6). AMP-PNP is represented in stick, and atoms are colored as follows: carbon - green; nitrogen blue; oxygen - red; phosphate - orange. (e and $\mathbf{h}$ ) Superposition of the ZmDRIK1 ATP binding site with AMP-PNP from the CARK1 structure. The protein molecular surface is shown in white with $50 \%$ transparency 
conformation might block ATP accommodation in the pocket. Leu ${ }^{240}$ belongs to the $\beta 2$-strand and interacts with the $\beta 1$-strand through the atoms from the main chain. This interaction stabilizes and exposes the side chain of this amino acid toward the ATP binding pocket. In addition, Leu ${ }^{375}$, which belongs to the Asp-Leu-Glu motif (commonly Asp-Phe-Gly), is stably oriented to the ATP binding pocket due to a series of interactions involving amino acids from C-helix, activation loop and catalytic loop. In C-helix, $\mathrm{Lys}^{275}$, which replaces the conserved Glu, interacts with the backbone of $\mathrm{Asp}^{374}$ and $\mathrm{Glu}^{376}$ from the Asp-Leu-Glu motif, supporting a conformation that induces the $l e u^{375}$ from the Asp-Leu-Glu motif side chain to face the ATP binding pocket. Hence, this conformation is stabilized by the interaction of conserved $\mathrm{Arg}^{355}$ (from the His-Arg-Asp-X-Lys-X-X-Asn motif) from the catalytic loop with the main chain of $\mathrm{Glu}^{376}$ and by the interaction between the side chain of $\operatorname{Trp}^{378}$ from the activation loop and $\mathrm{Asp}^{374}$ from the AspLeu-Glu motif. Together, these interactions force the side chain of Leu ${ }^{375}$ to be positioned towards the ATP binding pocket. Finally, the position of the side chain of $\mathrm{Tyr}^{363}$ is stabilized by Lys ${ }^{371}$ from the $\beta 7$ strand and $\mathrm{Gly}^{312}$ from the hinge. Interaction energy matrix (IEM) [49] analysis revealed that the side chains of these three amino acids also interact with favorable interaction energy $\left(\mathrm{Tyr}^{363}-\mathrm{Leu}^{375}:-5.75 \mathrm{~kJ} /\right.$ mol; $\mathrm{Tyr}^{363}-\mathrm{Leu}^{240}$ : $\quad-1.26 \mathrm{~kJ} / \mathrm{mol} ; \quad \mathrm{Leu}^{240}{ }^{2} \mathrm{Leu}^{375}$ : $5.49 \mathrm{~kJ} / \mathrm{mol}$ ).

To further elucidate the role of $\mathrm{Leu}^{240}, \mathrm{Tyr}^{363}$ and $\mathrm{Leu}^{375}$ in preventing ATP binding, we superimposed the apo structure of ZmDRIK1-KD (Fig. 4c and f) with AMP-PNP from the cocrystal structure of Cytosolic Aba Receptor Kinase 1 (CARK1) (Fig. 4d and g) [50]. It is possible to observe in the image superimposition (Fig. 4e and $\mathrm{h}$ ) that in the ATP-binding pocket of ZmDRIK1$\mathrm{KD}$, there is enough space to accommodate the nitrogen base of ATP between the hinge and the gatekeeper. The phosphate portion of ATP also does not have any obvious limitations in interacting with the ZmDRIK1-KD ATP-binding pocket. However, the side chains of Leu ${ }^{240}$, $\mathrm{Tyr}^{363}$ and $\mathrm{Leu}^{375}$ are oriented to the ATP-binding pocket, forming a barrier in the middle of the ATP binding pocket. In the superposition of AMP-PNP from CARK1 and ZmDRIK1-KD, it is possible that the sugar portion of ATP might be impaired by steric hindrance. Thus, this spine formed by the side chain of these three amino acids occludes the ATP binding pocket of $Z m D R I K 1-K D$, which might explain why nucleotide is unable to bind this kinase.

\section{The ATP pocket of ZmDRIK1-KD binds the ENMD-2076 small molecule}

Although ZmDRIK1-KD is not able to bind nucleotides, other molecules might interact with its ATP binding
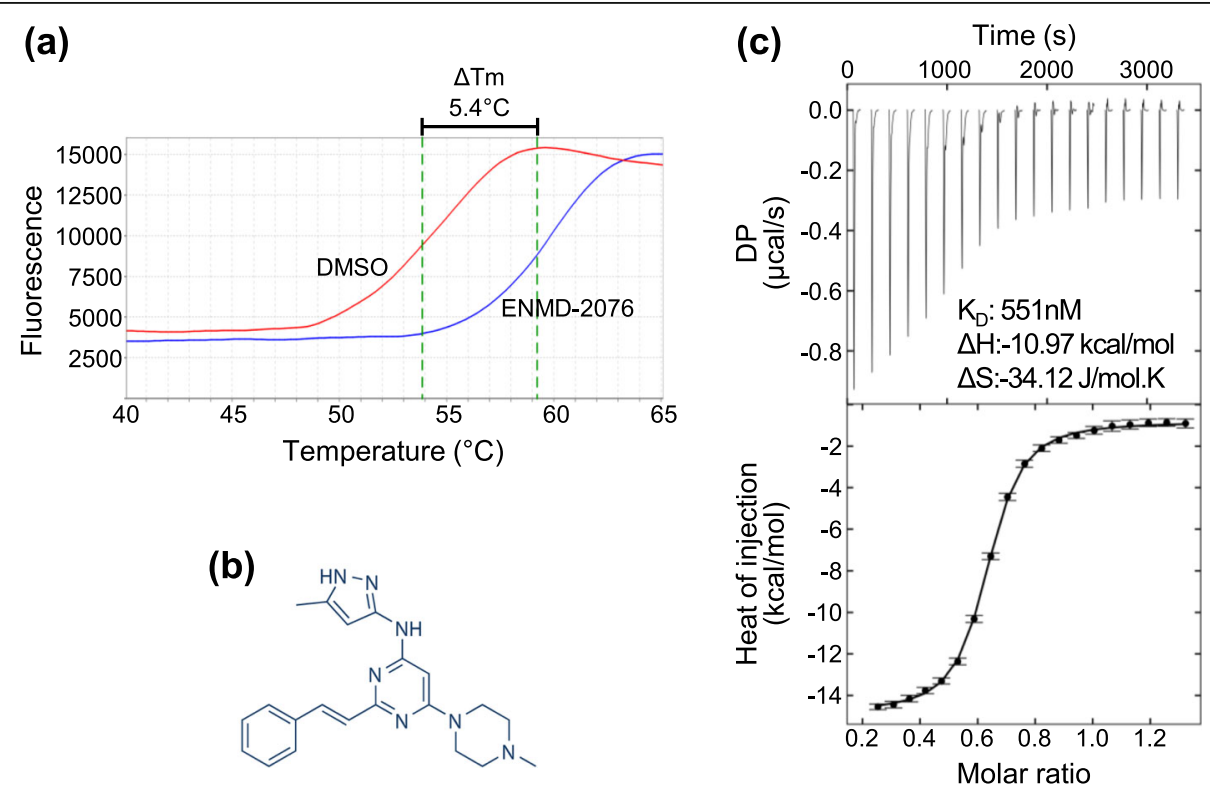

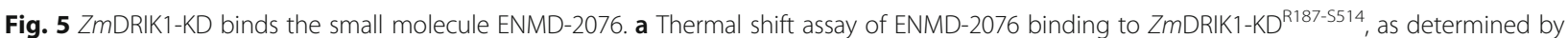
DSF. The compound stabilization is shown by the dislocation of the protein thermal denaturation midpoint (Tm) in the presence of ligand versus in DMSO only (red line). b Chemical structure of the ENMD-2076 molecule. c Determination of the thermal dynamic properties of the ENMD-2076 interaction with ZmDRIK1-KD ${ }^{\mathrm{R} 187-5514}$ by ITC 
pocket and regulate its activity. Using a DSF assay (Fig. 5a; Additional file 5: Figure S5) we screened a small molecule library of 378 compounds designed for human kinases and identified the ENMD-2076 compound (Fig. 5b). ENMD-2076 bind ZmDRIK1-KD with a $\Delta \mathrm{Tm}$ shift higher than $3.5^{\circ} \mathrm{C}$, which suggests that this molecule can thermally stabilize the kinase domain (Additional file 6: Table S1). The interaction of ENMD-2076 with $Z m$ DRIK1-KD ${ }^{\text {R187-S514 }}$ was further confirmed by ITC with a $K_{D}$ of $551 \mathrm{nM}$, indicating a high affinity binding mode (Fig. 5c).

DSF and ITC can be used to identify new ligands and elucidate the physical properties of the interaction. However, these assays do not show the interaction of the molecule with the protein at the molecular level. To gain insight into how ZmDRIK1 can bind to an ATP-competitive inhibitor, we solved the cocrystal structure of ZmDRIK1-KD bound to ENMD-2076. In this cocrystal structure, it is possible to observe that ENMD-2076 binds the ATP binding pocket and that its amine group from pyrimidine acts as a hydrogen donor for the $\mathrm{Ala}^{309}$ carbonyl from the hinge (Fig. 6b-dashed black line). When we compared the ATP-binding pocket of the ZmDRIK1-KD apo form (Fig. 6c) with the cocrystal (Fig. 6b), we observed no major changes induced by the small molecule ligand, especially in the hinge and the ATP binding pocket.

The piperazine from ENMD-2076 fits snugly in the cavity expected to be fulfilled by the nitrogen base of the ATP. The pyrazole is exposed to the solvent, and this group may be a target for modifications without compromising the interaction of ENMD-2076 with $Z m$ DRIK1-KD. The styrene is oriented to the cavity believed to be occupied by the phosphates from ATP. Unlike ATP, the side chain of the triad $\mathrm{Leu}^{240}, \mathrm{Tyr}^{363}$ and $\mathrm{Leu}^{375}$ did not impair the interaction with ENMD-2076.

\section{Discussion}

The analysis of global expression patterns in an organism using the transcriptome helps elucidate how metabolism adapts in response to stress. However, transcriptome experiments do not demonstrate the role of individual proteins in normal or stressed metabolism. Nevertheless, using public databases to identify genes that have an expression pattern regulated by metabolic perturbations can be the starting point to elucidate their role. In this work, we identified $Z m D R I K 1$, a conserved receptor-like pseudokinase that is regulated by biotic and abiotic stress.

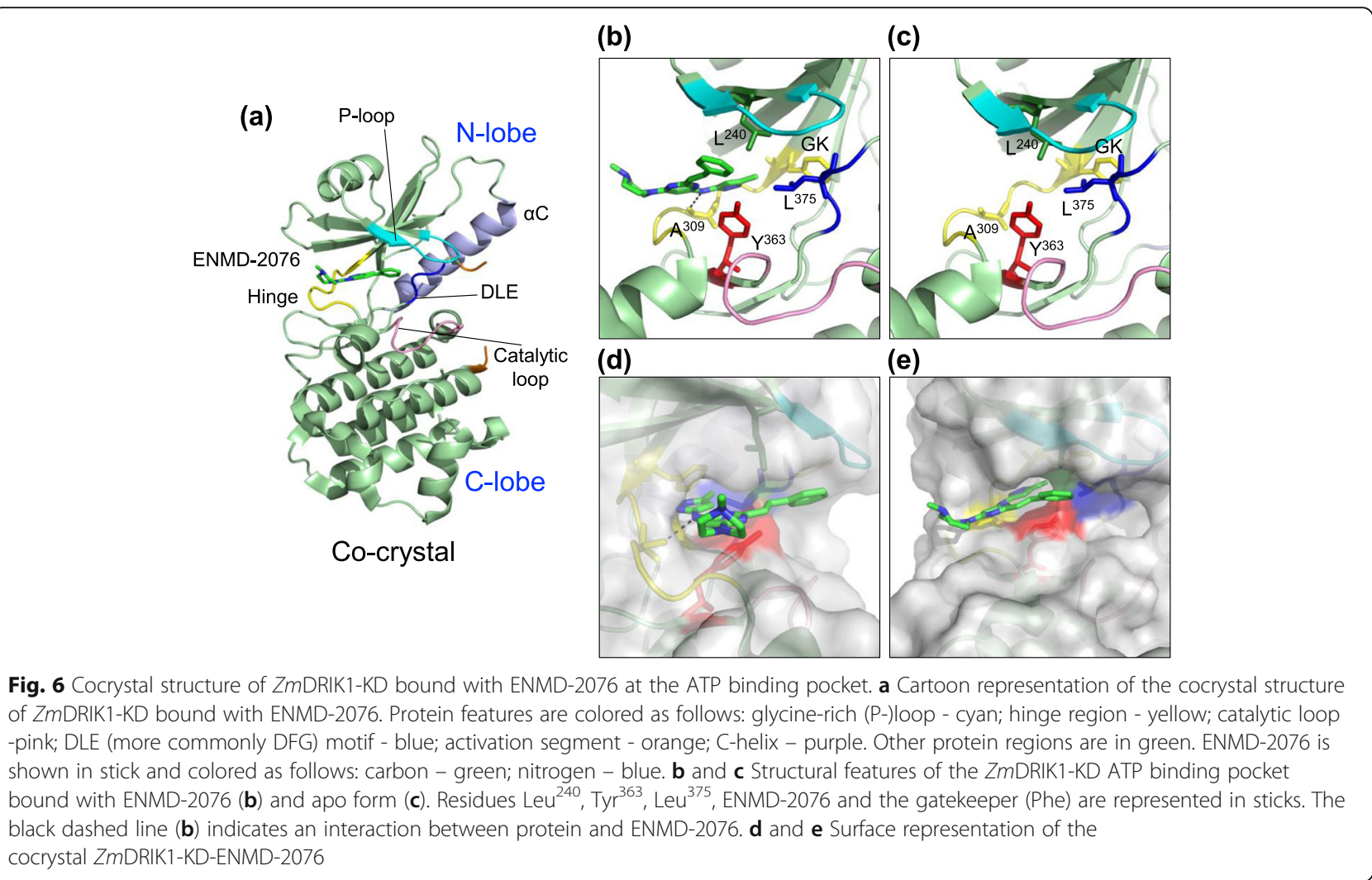


Pseudokinases have emerged as important signaling players that regulate cell metabolism by recruiting other proteins and thereby activating a responsive pathway [23, 36]. In Arabidopsis, the interaction between Clavata2 (CLV2), a receptor-like protein (LRR-RLP), and Coryne, a receptor-like pseudokinase, is important for stem cell maintenance in shoots [32]. Despite a lack of transferase activity, the kinase domain of Coryne is necessary to promote the endoplasmic reticulum-to-plasma membrane migration of CLV2, indicating that even without phosphorylation activity, these kinases have important roles in plant metabolism. In maize, stomata formation is dependent on two other receptor-like pseudokinases, PAN1 and PAN2 [51, 52]. These two pseudokinases participate in a series of events that polarize first PAN2 and then PAN1 to promote asymmetric cell division of a precursor subsidiary mother cell generating functional stomata [53]. In pan1- or pan2knockouts, the subsidiary mother cells did not undergo asymmetric cell division; thus, malformed stomata are produced, implicating in nonfunctional stomata. Moreover, pseudokinases also have roles in the response to biotic and abiotic stress. In response to biotic stress in Arabidopsis, a cytoplasmic pseudokinase named HOPZ-ETI-DEFICIENT 1 (ZED1), is essential to respond to Pseudomonas syringea infection [54]. This pseudokinase serves as a decoy to HopZ1a, an infection effector, in the ZAR1-mediated immunity response. Another pseudokinase important to respond to abiotic stress is GHR1. This LRR-RLK is necessary to activate SLAC1 and promote stomatal closure [26]. It was proposed that this pseudokinase don't phosphorylate SLAC1 but serve as a scaffold for additional regulators, such as CPK3. The widespread relevance of plant pseudokinases must become even more complex as more proteins are characterized. In particular, considering the increasing number of human pseudokinases involved in a variety of functions, binding partners, conformations and molecular mechanisms of action [25]. In this study, we identified the pseudokinase ZmDRIK1 that is phylogenetically, genetically structurally conserved among different plant species but less conserved among the other representative members of the same subfamily LRR-VI-2. The conserved gene structure in maize, sorghum and rice suggests a similar function in these plants, as well as a common ancestor during evolution [55]. Although the tandem duplication of a few subfamilies of RLK/Pelle has been described [8], the missed paralogous relationship between ZmDRIK1 and other members of the same subfamily was not surprising, as the gene duplications of pseudokinases are believed to be evolved from canonical kinases [56], while all 6 other members of LRR-VI-2 from maize are also predicted to be pseudokinase [10]. In addition, the sequence alignment of maize genes from LRR-VI-2 showed very low similarity with $Z m D R I K 1$, while their kinase domains are highly conserved, corroborating the remarkable aspect of both known and putative dead kinases retaining selected constraints of conserved kinase domain sequences [10] and divergences in extracellular domains $[4,6]$. Little is known about the molecular function of pseudokinases in general but particularly from the LRR-VI subfamily $[10,57]$. Among these pseudokinases, only two members were previously characterized in Arabidopsis, MDIS1 and MDIS2. The MDIS1/ Male discover 1 was found to form heterodimers with receptors MDIS1-Interacting Receptor Kinases MIK1 and MIK2 on the pollen tube that perceives female attractant LURE1 [58]. Although predicted as a pseudokinase, MDIS1 can be phosphorylated by MIK1 [58], acting as a putative coreceptor [59]. The MDS2 (MRH1, [60]) was described as being associated with root hair formation and interacting with the plant potassium channel AKT2 [60, 61]. Our phylogenetic and gene structure analyses revealed that DRIK1 is probably functionally distinct from these two previously characterized proteins.

Pseudokinases are characterized by the absence of conserved amino acids for kinase activity; despite compromised phosphorylation, several of these proteins retain the ability to bind ATP [62]. On the other hand, some catalytically active RLKs have dispensable kinase domains, depending on the pathway-specific factor interaction [32, 63, 64]. In plants, BSK8, a pseudokinase involved in brassinosteroid signaling, binds to ATP in an unusual conformation, and the complex protein:nucleotide might regulate other proteins [46]. However, for $Z m D R I K 1$, ATP binding was not observed. Similarly, the pseudokinase BIR2, a negative regulator of the BAK1mediated defense mechanism, also doesn't bind to ATP; in this case, the unusual position of the P-loop forms a barrier that occludes the ATP binding site [29]. Although the ATP binding pocket is exposed to the solvent in ZmDRIK1, the P-loop doesn't show the consensus sequence common to active kinase, and the interaction between $\mathrm{Thr}^{237}$ and $\mathrm{Glu}^{376}$ (from Asp-Leu-Glu motif) suggests that this structure is more rigid and may compromise ATP exchange, as observed by Kwon et al. (2019) [10]. Moreover, the conserved Asp-Phe-Gly motif and Glu from C-helix which, in active kinases, interact with each other and the catalytic lysine are substituted by Asp-Leu-Glu and Lys, respectively. These mutations cause a rearrangement in the interaction in this core, leading to a stable conformation of the Asp-Leu-Glu motif that position the side chain of $\mathrm{Leu}^{375}$ oriented to the ATP binding pocket. Hence, the interaction between the $\beta 1$-strand and $\beta 2$-strand also positions the side chain of $\mathrm{Leu}^{240}$ in the ATP binding pocket, and $\mathrm{Tyr}^{363}$ is stabilized by interaction with amino acids from the hinge and $\beta 7$-strand. Although these three amino acids occupy the ATP binding pocket, this cavity is structured and accessible and might bind to other molecules, such as ENMD2076. This small ligand, in addition to blocking ATP 
binding, can also preferentially stabilize ZmDRIK1 in a conformational state able to activate or inactivate the protein, similar to that observed in several human kinases and pseudokinases with small-molecule binding [25]. Using the cocrystal structure, these molecules can be rationally designed to elucidate the protein's role in plant metabolism.

Bioinformatics analysis of the ZmDRIK1 expression pattern using publicly available RNA-seq data from maize also suggests a possible role for ZmDRIK1 in plant development: the upregulated expression during maize germination and downregulation under a variety of stress conditions suggests the growth regulation in detriment of alert-state status to defense under stress conditions. This mechanism of stress response generally comes at the cost of reduced growth $[65,66]$. On the other hand, this gene might act as an inhibitor of stress response. In this case, under normal conditions, this gene kept the stress response pathway inactivated, and when plants must respond to stress, the protein levels decrease, releasing the responsive pathway. Once the stress condition ends, the protein levels increase to inhibit the stress response pathway. Thus, to answer this question, further physiological data will be necessary and are beyond the structural scope of the current study. Genetic modulation "in plants" will be an important tool to elucidate if the protein kinase fold devoid of catalytic activity is dispensable for $Z m D R I K 1$ function in maize, whereas small molecules, such as ENMD-2076 and improved derivatives could be used for modulation of $Z m D R I K 1$ functions through the design of conformation-specific inhibitors.

\section{Conclusions}

$Z m$ DRIK1 is a novel receptor-like pseudokinase responsive to biotic and abiotic stress. The absence of ATP binding and consequently, the absence of phosphorylation activity, was proven by the crystal structure of the apo form of the protein kinase domain. The side chains of amino acid triad $\mathrm{Leu}^{240}, \mathrm{Tyr}^{363}$ and Leu ${ }^{375}$ faces the ATP-binding pocket, forming a barrier. The spine formed by the side chain of these three amino acids occludes the ATP pocket preventing the nucleotide binding.

The expression profiling of the gene encoding $Z m$ DRIK1 suggests this kinase may play a role in downregulating the expression of stress responsive genes that are not necessary under normal conditions. However, when plants are subjected to biotic and abiotic stress, $Z m D R I K 1$ is down-regulated to release the expression of stress-responsive genes.

\section{Methods}

Identification of maize kinases down-regulated by drought stress and other perturbations

The Genevestigator database [41] was used to select candidate genes responsive to stress. By analyzing the gene expression of plants subjected to drought treatments, promising targets were selected for further characterization, including Zm00001d028770, which encodes $Z m$ DRIK1. The publicly available maize microarray data from Zheng et al. 2010 [40] was chosen to investigate RLKs showing downregulation under drought and upregulation under rewatering treatments in Han21 and Ye478 drought-tolerant and drought-sensitive maize lines, respectively. As one of the top 10 candidates, $Z m D R I K 1$ showed differential expression log-ratio $>2$ in all 4 samples (both genotypes and treatment). All other transcriptional expression profiles of ZmDRIK1 under different perturbation conditions were analyzed from experimental data available in the Genevestigator database. The experimental data were retrieved from Genevestigator, analyzed and compiled using GraphPad Prism version 6.01 for Windows (GraphPad Software, La Jolla, USA). Unless otherwise specified, all the expression data were from the mRNA-Seq platform and were from the B73 inbred line.

\section{Plant material and growth conditions}

Maize (Zea mays) inbred line B73 were obtained from Maize Genetics Cooperation Stock Center (http://maizecoop.cropsci.uiuc.edu). Seeds were surface sterilized by immersion in $15 \%$ sodium hypochlorite solution containing $0.1 \%$ Tween 20 for 15 min followed by eight washes in distilled water. The seeds were enrolled in paper towel and incubated at $28^{\circ} \mathrm{C}$ for $72 \mathrm{~h}$, and the seedlings were subsequently harvested or transplanted to pots containing a mixture of soil and vermiculite 1:1 $(\mathrm{w} / \mathrm{w})$ and grown for 15 days in a growth chamber at $28^{\circ} \mathrm{C}$ and $16 / 8 \mathrm{~h}$ day/ night. Leaves and roots were sampled and immediately frozen in liquid nitrogen before being used for qPCR analysis. For the drought stress experiments, seedlings were grown in pots containing a mixture of sphagnum:perlite (7:1 v/v) supplied with PG Mix YARA 14-16-18 under controlled conditions of $25^{\circ} \mathrm{C}$ for $16 \mathrm{~h}$ light and $\sim 45 \%$ relative humidity. Progressive drought stress was introduced 8 days after sowing by irrigation restriction for 9,12 or 14 days, while control plants were well-watered. Leaves were harvested, immediately frozen in liquid nitrogen, and stored at $-80^{\circ} \mathrm{C}$ before use.

\section{Cloning, expression and purification of ZmDRIK1 kinase domain (ZmDRIK1-KD)}

cDNA from the maize B73 inbreed line prepared from total RNA isolated from young leaves was used as a template for the amplification of a DNA fragment encoding the ZmDRIK1 kinase domain. Two forward primers (drik1-Arg ${ }^{187}$-F - TACTTCCAATCCATGCGAGCTAAG AAAATGGGAACCG); drik1-Lys ${ }^{217}$-F - TACTTCCAAT CCATGAAACGATCAGAGCTGGAAACGG) and two reverse primers (drik1-Ser ${ }^{514}-\mathrm{R}$ - TATCCACCTTTACT 
GTCAGCTCTCAGAAGTCATAATCTCAAGC); drik1$\mathrm{Pro}^{488}$-R - TATCCACCTTTACTGTCAAGGCCCTA GCGCGG) were designed. The combination of these primers generated four constructs spanning the $Z m D R I K 1$ kinase domain (residues $\mathrm{Arg}^{187}-\mathrm{Ser}^{514}$; $\mathrm{Lys}^{217}-\mathrm{Ser}^{514}$; $\mathrm{Arg}^{187}$-Pro $^{492}$; $\mathrm{Lys}^{217}-\mathrm{Pro}^{492}$ ). Amplicons were treated with T4-DNA polymerase for ligase-independent cloning (LIC) [67] and cloned in pNIC28a-Bsa4 [67]. Confirmation of positive clones was made by colony PCR and sequencing.

Plasmid pNIC28a-Bsa4 harboring each construct was transformed into BL21(DE3)-pRARE, and colonies were inoculated in $30 \mathrm{~mL}$ of $\mathrm{LB}$ medium and grown overnight in a shaker at $37^{\circ} \mathrm{C}$. Cultures were diluted in $1.5 \mathrm{~L}$ of $\mathrm{TB}$ medium and grown until $\mathrm{OD}_{600}$ reached 1.5-2. Cultures were cooled to $18^{\circ} \mathrm{C}$, and protein synthesis was induced overnight by 0.2 mM IPTG. Bacteria were harvested by centrifugation at $5,000 \mathrm{x} \mathrm{g} ; 10 \mathrm{~min} ; 4{ }^{\circ} \mathrm{C}$, suspended in $2 \mathrm{x}$ binding buffer ( $1 \mathrm{x}$ binding buffer is $50 \mathrm{mM}$ HEPES pH 7.4, $500 \mathrm{mM} \mathrm{NaCl}, 5 \%$ glycerol, $10 \mathrm{mM}$ imidazole, and 1 $\mathrm{mM}$ TCEP) with $1 \mathrm{mM}$ of PMSF and stored at $80^{\circ} \mathrm{C}$.

The suspended pellets were thawed, and the cells were lysed by sonication for $12 \mathrm{~min}$ ( $5 \mathrm{~s} \mathrm{ON;} 10 \mathrm{~s}$ OFF; Amp 30\%). One milliliter of 5\% polyethyleneimine was added per $30 \mathrm{ml}$ of lysate, and the lysate was then clarified by centrifugation at $40,000 \mathrm{x} \mathrm{g} ; 45 \mathrm{~min} ; 4^{\circ} \mathrm{C}$. The supernatant was loaded onto an IMAC column $(5$ ml HisTrap FF Crude, GE Healthcare, Uppsala, Sweden), and contaminants were washed with a binding buffer with $30 \mathrm{mM}$ imidazole. The recombinant protein was eluted with $300 \mathrm{mM}$ imidazole in binding buffer. Eluted protein was treated with TEV protease to remove the 6xHIS-tag. Contaminants and the tag were removed using nickel beads. As the last step of purification, proteins were injected onto a size exclusion HiLoad 16/60 Superdex 200 pg (GE Healthcare, Uppsala, Sweden) column equilibrated with binding buffer without imidazole. Fractions of purified protein were pooled together and stored at $-80^{\circ} \mathrm{C}$.

\section{Isothermal calorimetry}

Isothermal calorimetry (ITC) was used to determine the interaction between $Z m D R I K 1-K^{\mathrm{R} 187-S 514}$ with nucleotides and small molecule ligands. For the nucleotide, $50 \mu \mathrm{M}$ of purified $Z m$ DRIK1-KD ${ }^{\text {R187-S514 }}$ (cell) was titrated with $1 \mathrm{mM}$ GTP or the ATP ana$\log$ AMP-PNP (injectant) in ITC buffer containing $50 \mathrm{mM} \mathrm{K}$-phosphate pH 7.5, $500 \mathrm{mM} \mathrm{NaCl}, 5 \%$ glycerol, $1 \mathrm{mM}$ TCEP and $5 \mathrm{mM} \mathrm{MgCl}$. For the small molecule ligands, $50 \mu \mathrm{M}$ of ENMD-2076 (cell) was titrated with $300 \mu \mathrm{M}$ of $Z m D R I K 1-K^{\mathrm{R} 187-\mathrm{S} 514}$ (injectant) in ITC buffer without magnesium. The heat of interactions was measured on a MicroCal Auto iTC200 (GE/Malvern Panalytical, Northampton, UK), with titrations at $25{ }^{\circ} \mathrm{C}$ in a stirring speed of $750 \mathrm{rpm}$ and $300 \mathrm{~s}$ between each $2 \mu \mathrm{L}$ injection. Dilution heat were measured titrating buffer and ligands alone and then subtracted from protein-ligand data. Protein concentrations used in this experiment were measured using Edelhock method [68]. Data were analyzed using NITPIC, version 1.2.2 and Sedphad, version $12.1 \mathrm{~b}$ software. Figures were generated in GUSSI version 1.3.2 [69].

\section{Crystallization, data collection, structure determination and refinement}

ZmDRIK1-KD was crystallized in the apo form and bound to ENMD-2076. For the apo form, $857 \mu \mathrm{M}$ of purified $Z m D R I K 1-K^{\mathrm{R} 187-5514}$ was centrifuged for $10 \mathrm{~min}$ at 21 , $130 \mathrm{x}$ g at $4{ }^{\circ} \mathrm{C}$, and a 150 -nL-volume drop was pipetted by mixing purified protein and crystallization solution from the JCSG-plus HT96 (Molecular Dimension, Maumee, USA) crystallization screen at three ratios (2:1, 1:1, 1:2). For cocrystallization, purified $Z m D R I K 1-K D^{\text {R187-S514 }}$ was incubated with ENMD-2076 at a threefold molar excess for 30 $\mathrm{min}$ on ice. Mixtures were centrifuged for $10 \mathrm{~min}$ at 21,130 $\mathrm{x} \mathrm{g}$ at $4{ }^{\circ} \mathrm{C}$, and 150 -nL-volume drops were pipetted at three ratios $(2: 1 ; 1: 1 ; 1: 2)$ using a custom optimization crystallization screen (Molecular Dimension, Maumee, USA). Crystallization plates were incubated at $20^{\circ} \mathrm{C}$ until crystals appeared. Crystals were collected in a cryoprotectant solution (reservoir solution supplemented with 30\% glycerol) and flash-frozen in liquid nitrogen. Diffraction data were collected at the Advanced Photon Source (APS) or Diamond Light Source (DLS). Data were processed using first XDS [70] and latter AIMLESS, from CCP4 software suite [71]. Phaser [72, 73] was used to perform the molecular replacement with the kinase domain of SUCROSE INDUCED RECEPTOR KINASE 1 (SIRK1) (PDB: 5UV4). After the model was built, the refinement of the structure was made using Coot [74] followed by the validation of the structure factors and coordinates using MolProbity [75]. Structure factors and coordinates (Table 1) were deposited in the Protein Data Bank with accession number 6CPY for the apo form and 6EAS for the cocrystal.

\section{Differential scanning fluorimetry (DSF)}

A cell-permeable ATP-competitive kinase inhibitor library from Selleckchem (Houston, TX, United States; catalog No. L1200) was screened to identify interactors for $Z m D R I K 1-K D$. One micromolar of each purified construct of ZmDRIK1-KD was mixed with DSF buffer (100 mM K-phosphate, $150 \mathrm{mM} \mathrm{NaCl}, 10 \%$ glycerol, and $\mathrm{pH}$ 7.5) containing 1:1000 SYPRO Orange Protein Thermal Shift Dye (Life Technologies Corporation, Eugene, USA) in a 384-well plate containing $10 \mu \mathrm{M}$ of each library 
Table 1 Crystallographic data

\begin{tabular}{|c|c|c|}
\hline Data collection & $Z m D R \mid K 1-K D$ apo & $\begin{array}{l}Z m D R I K 1-K D+E N M D- \\
2076\end{array}$ \\
\hline X-ray source & $\begin{array}{l}\text { APS BEAMLINE } \\
24-I D-E\end{array}$ & $\begin{array}{l}\text { DIAMOND } \\
\text { BEAMLINE I24 }\end{array}$ \\
\hline Wavelength $(\AA)$ & 0.979180 & 0.976230 \\
\hline Space group & P 212121 & P 21221 \\
\hline $\begin{array}{l}\text { Cell dimensions }(\AA) \text { a }, b, c \\
(\AA)\end{array}$ & 61.4961 .5144 .76 & 60.5161 .7965 .38 \\
\hline Resolution $(\AA)$ & $19.82-1.7$ & $28.9-2.0$ \\
\hline No. of unique reflections & $58,167(2974)$ & $17,144(1238)$ \\
\hline Rmerge (\%) & $6.4(203)$ & $5.5(87.1)$ \\
\hline Mean l/øl & $16.4(1.62)$ & $14.6(2.0)$ \\
\hline Completeness (\%) & $99.9(99.9)$ & $99.9(100)$ \\
\hline Redundancy & $10.9(10.7)$ & $6.4(6.8)$ \\
\hline $\mathrm{CC}^{1} / 2$ & $0.99(0.519)$ & $0.99(0.72)$ \\
\hline \multicolumn{3}{|l|}{ Refinement } \\
\hline Resolution range $(\AA)$ & $19.82-1.7$ & $28.9-2.0$ \\
\hline R/Rfree (\%) & $19.9 / 21.5$ & $20.81 / 25.08$ \\
\hline Mean B-factor $(\AA)$ & 35.0 & 48.0 \\
\hline r.m.s.d. bond lengths ( $\AA$ ) & 0.0066 & 0.0072 \\
\hline $\begin{array}{l}\text { r.m.s.d. bong angles } \\
\text { (degrees) }\end{array}$ & 1.10 & 1.11 \\
\hline \multicolumn{3}{|c|}{ Ramachandran plot statistics (\%) } \\
\hline Preferred regions & 99.05 & 99.61 \\
\hline Outlier & 0.0 & 0.0 \\
\hline PDB ID & $6 \mathrm{CYP}$ & 6EAS \\
\hline Crystallization conditions & $\begin{array}{l}0.15 \mathrm{M} \text { potassium } \\
\text { bromide, } 30 \% \\
\text { PEG2000 MME }\end{array}$ & $\begin{array}{l}1 \text { mM zinc chloride; } \\
22 \% \text { PEG6000; } \\
100 \text { mM MES; pH } 6.0\end{array}$ \\
\hline
\end{tabular}

compound. As compound stocks were stored at $10 \mathrm{mM}$ in $100 \%$ DMSO, a control with $0.1 \%$ DMSO was used as a reference. Plates were sealed using optically clear films, and fluorescence intensity data were measured in a temperature gradient from 25 to $95^{\circ} \mathrm{C}$ at a constant rate of $0.05^{\circ} \mathrm{C} / \mathrm{s}$ in a QuantStudio $6 \mathrm{qPCR}$ instrument (Applied Biosystems, Singapore). Data were analyzed using the Boltzmann function. Compounds with increased melting temperature by $2{ }^{\circ} \mathrm{C}$ or more, in comparison to the control curve, were considered positives.

\section{Phylogenetic analyses}

Amino acid sequences of ZmDRIK1-related plant RLK/ Pelle-LRRs were retrieved from maize GDB [76], Phytozome12 [77], PLAZA 4.0 [78], TAIR [79], EnsemblPlants [80], and NCBI Databases [81] (Additional File 7: Table S2). The programs iTAK [82] and PlantsP [83] were used to annotate the kinase groups. Sequences were aligned using ClustalX [84], and the phylogenetic tree was generated with MEGA 6 [85] using the Neighbor-Joining method
[86] and 1000 bootstrap replicates. The evolutionary distances were computed using the Poisson correction method [87] and were expressed as units of amino acid substitutions per site. The analyses included all $A$. thaliana and $Z$. mays subfamily LRR-VI-2 representative proteins, and orthologues of ZmDRIK1 from other species (Additional file 7: Table S2). The out-group sequences from Arabidopsis are represented by other subfamilies: catalytically inactive BSK8 [46], catalytically active SERK1 [88], BRI1 [89], and CLV1 [90]. The RLK/Pelle subfamily groups are classified as proposed by Lehti-Shiu et al. 2009 [8] and 2012 [91].

\section{Quantitative real-time PCR}

Total RNA was extracted from the leaves and roots of 3and 15-day-old B73 maize plants or leaves of drought stressed B73 maize. Samples were powdered in liquid nitrogen, and 100-200 mg powder was mixed with $1 \mathrm{~mL}$ of TRIzol (Invitrogen, Carlsbad, USA) and vortexed. After $10 \mathrm{~min}$ of incubation at room temperature, $200 \mu \mathrm{L}$ of chloroform was added and vortexed briefly. Samples were centrifuged for $15 \mathrm{~min}$ at $12,000 \mathrm{x}$ g at $4{ }^{\circ} \mathrm{C}$, the aqueous phase was collected, and RNA was purified using a PureLink RNA kit (Life Technologies, Carlsbad, USA) according to the manufacturer's instructions. After checking for RNA quality and integrity by agarose gel, cDNAs were synthesized using SuperScript III reverse transcriptase (Invitrogen, Carlsbad, USA). Five micrograms of total RNA were incubated with oligo dT20 and dNTP for $5 \mathrm{~min}$ at $65^{\circ} \mathrm{C}$ and then cooled on ice. Buffer, DTT and SuperScript enzyme were added and incubated for $60 \mathrm{~min}$ at $50^{\circ} \mathrm{C}$. The enzyme was inactivated for $15 \mathrm{~min}$ at $70^{\circ} \mathrm{C}$, and the cDNA was stored at $-20^{\circ} \mathrm{C}$ until use.

Quantitative real-time PCR (qRT-PCR) was performed in a $10 \mu \mathrm{L}$ reaction mixture using $5 \mu \mathrm{L}$ of $2 x$ Luna universal qPCR master mix (New England Biolabs), $0.5 \mu \mathrm{M}$ of each primer (Additional file 8: Table S3) and $3 \mu \mathrm{L}$ of 20 -fold diluted cDNA. qRT-PCR was performed in QuantStudio 6 (Applied Biosystems, Singapore), and the PCR conditions were as follows: $50^{\circ} \mathrm{C}$ for $2 \mathrm{~min}, 95^{\circ} \mathrm{C}$ for $10 \mathrm{~min}, 40 \mathrm{cycles}$ of $95^{\circ} \mathrm{C}$ for $15 \mathrm{~s}$ and $60^{\circ} \mathrm{C}$ for 1 $\mathrm{min}$. To analyze if single products were formed, a melting curve (starting at $60^{\circ} \mathrm{C}$ and increasing by $0.05^{\circ} \mathrm{C} / \mathrm{s}$ until reaching $95^{\circ} \mathrm{C}$ ) at the end of the qPCR was performed. The $\beta$ TUB, CYP, and EIF4a genes were used as internal controls. qRT-PCR data were analyzed using QuantStudio Real-time PCR software (version 1.3). Quantification was performed with the $\Delta \Delta \mathrm{Ct}$ method of three replicates and expressed as relative mRNA expression. Pairwise comparisons of mRNA level between different tissues and plant age, or between drought-stressed and rewatered samples, were calculated using a twotailed Student's t-test. All data analyses were conducted using GraphPad Prism version 6.01 for Windows (GraphPad Software, La Jolla, USA). 


\section{Supplementary information}

Supplementary information accompanies this paper at https://doi.org/10. 1186/s12870-020-2328-3.

Additional file 1: Figure S1. Identification of $Z m D R I K 1$ as a promising drought stress related receptor kinase.

Additional file 2: Figure S2. DRIK1 and maize RLKs present a diversified gene structure but conserved protein kinase domain.

Additional file 3: Figure S3. $D R I K 1$ transcript level is downregulated by stress perturbations in maize.

Additional file 4: Figure S4. $D R I K 1$ transcript level is increased during germination in maize.

Additional file 5: Figure S5. $Z m D R I K 1-K D$ bind the small molecule ENMD-2076.

Additional file 6: Table S1. Small molecule library thermal profiling for DRIK1 hits identification.

Additional file 7: Table S2. Protein IDs used for in silico analysis of ZmDRIK1.

Additional file 8: Table S3. Primers used in the RT-qPCR experiments. Additional file 9: Figures S6-S7. Original SDS-PAGE gels presented in Fig. 3b.

\section{Abbreviations}

ABA: Abscisic acid; ATP: Adenosine triphosphate; DAS: Days after sowing; DSF: Differential scanning fluorimetry; GTP: Guanosine triphosphate; IEM: Interaction energy matrix; IMAC: Immobilized metal affinity chromatography; ITC: Isothermal calorimetry; KD: Kinase domain; LIC: Ligase independent cloning; LRR: Leucine-rich repeat; qRT-PCR: quantitative realtime PCR; RLK: Receptor-like kinase; Zm: Zea mays

\section{Acknowledgements}

We thank the staff of the Life Sciences Core Facility (LaCTAD) from State University of Campinas (UNICAMP) for the ITC analysis. We thank Rafael M. Couñago for assisting with the crystallography and for critically reading this manuscript. This work used NE-CAT beamline 24-ID-E at the Advanced Photon Source (DE-AC02-06CH11357) through proposal GUP-54127 and beamline 103 at the Diamond Light Source through proposal MX15433-54.

\section{Authors' contributions}

BA, VCHS, KM and PA established the grounds for this project. BA and VCHS designed and performed the experiments and analyzed the data. BA, VCHS and PA wrote the article. All authors have read and approved the manuscript.

\section{Funding}

BA and VCHS are FAPESP postdoctoral fellows (2017/19609-6 and 2018/ 06442-9, respectively). This work was supported by the following funders: FAPESP grants to PA through the Genomics for Climate Change Research Center (2016/23218-0) and INCT (FAPESP 2014/50897-0 / CAPES/CNPQ). These grants supported the laboratory infra structure, equipment and consumables for the execution of experiments. The structural biology experiments was supported by SGC that is a registered charity (number 1097737) that receives funds from AbbVie, Bayer Pharma AG, Boehringer Ingelheim, Canada Foundation for Innovation, Eshelman Institute for Innovation, Genome Canada, Innovative Medicines Initiative (EU/EFPIA) [ULTRA-DD grant no. 115766], Janssen, Merck KGaA Darmstadt Germany, MSD, Novartis Pharma AG, Ontario Ministry of Economic Development and Innovation, Pfizer, São Paulo Research Foundation-FAPESP, Takeda, and the Wellcome Trust [106169/ZZ14/Z]. PA is a CNPq productivity research fellow. The funding bodies had no role in design of the study and collection, analysis, and interpretation of data and in writing the manuscript.

\section{Availability of data and materials}

The crystallography dataset generated during the current study are available in the PDB repository (http://www.rcsb.org/structure/6CPY; http://www.rcsb. org/structure/6EAS). Other datasets used and/or analyzed during the current study are available from the corresponding author on reasonable request.
Ethics approval and consent to participate

Not applicable.

\section{Consent for publication}

Not applicable.

\section{Competing interests}

The authors declare that they have no competing interests.

\section{Author details}

${ }^{1}$ Structural Genomics Consortium, Universidade Estadual de Campinas UNICAMP, Campinas, SP 13083-886, Brazil. Joint Research Center for Genomic Applied to Climate Change (UMIP-GenClima), Campinas, SP 13083-875, Brazil. ${ }^{3}$ Centro de Biologia Molecular e Engenharia Genética, Universidade Estadual de Campinas (UNICAMP), Campinas, SP 13083-875, Brazil. ${ }^{4}$ Departamento de Genética e Evolução, Instituto de Biologia, Universidade Estadual de Campinas (UNICAMP), Campinas, SP 13083-970, Brazil.

Received: 20 June 2019 Accepted: 4 March 2020

Published online: 15 April 2020

\section{References}

1. Marshall A, Aalen RB, Audenaert D, Beeckman T, Broadley MR, Butenko MA, Caño-Delgado Al, de Vries S, Dresselhaus T, Felix G, Graham NS, Foulkes J, Granier C, Greb T, Grossniklaus U, Hammond JP, Heidstra R, Hodgman C, Hothorn M, Inzé D, Ostergaard L, Russinova E, Simon R, Skirycz A, Stahl Y, Zipfel C, De Smet I. Tackling drought stress: receptor-like kinases present new approaches. Plant Cell. 2012:24:2262-78.

2. Ye $Y$, Ding $Y$, Jiang $Q$, Wang $F$, Sun J, Zhu C. The role of receptor-like protein kinases (RLKs) in abiotic stress response in plants. Plant Cell Rep. 2017;36:235-42.

3. Couto D, Zipfel C. Regulation of pattern recognition receptor signaling in plants. Nat Rev Immunol. 2016;16:537-52

4. Hohmann U, Lau K, Hothorn M. The structural basis of ligand perception and signal activation by receptor kinases. Annu Rev Plant Biol. 2017;68:10937.

5. Shiu SH, Bleecker AB. Expansion of the receptor-like kinase/Pelle gene family and receptor-like proteins in Arabidopsis. Plant Physiol. 2003;132:530-43.

6. Shiu SH, Karlowski WM, Pan R, Tzeng YH, Mayer KF, Li WH. Comparative analysis of the receptor-like kinase family in Arabidopsis and rice. Plant Cell. 2004;16:1220-34.

7. Wei K, Wang Y, Xie D. Identification and expression profile analysis of the protein kinase gene superfamily in maize development. Mol Breed. 2014;33: 155-72.

8. Lehti-Shiu MD, Zou C, Hanada K, Shiu SH. Evolutionary history and stress regulation of plant receptor-like kinase/pelle genes. Plant Physiol. 2009;150: $12-26$.

9. Gou X, He K, Yang H, Yuan T, Lin H, Clouse SD, Li J. Genome-wide cloning and sequence analysis of leucine-rich repeat receptor-like protein kinase genes in Arabidopsis thaliana. BMC Genomics. 2010;11:19.

10. Kwon A, Scott S, Taujale R, Yeung W, Kochut KJ, Eyers PA, Kannan N. Tracing the origin and evolution of pseudokinases across the tree of life. Sci Signal. 2019;12:eaav3810

11. Zhang Z, Thomma BP. Structure-function aspects of extracellular leucinerich repeat-containing cell surface receptors in plants. J Integr Plant Biol. 2013:55:1212-23.

12. de Smet I, Voss U, Jurgens G, Beeckman T. Receptor-like kinases shape the plant. Nat Cell Biol. 2009;11:1166-73.

13. Zhang H, Lin X, Han Z, Wang J, Qu L-J, Chai J. SERK family receptor-like kinases function as co-receptors with PXY for plant vascular development. Mol Plant. 2016:9:1406-14

14. Gómez-Gómez L, Boller T. FLS2: an LRR receptor-like kinase involved in the perception of the bacterial elicitor flagellin in Arabidopsis. Mol Cell. 2000;5: 1003-11.

15. Chen X, Chern M, Canlas PE, Jiang C, Ruan D, Ronald PC. A conserved threonine residue in the juxtamembrane domain of the XA21 pattern recognition receptor is critical for kinase autophosphorylation and XA21 mediated immunity. J Biol Chem. 2010;285:10454-63. 
16. Fontes EPB, Santos AA, Luz DF, Waclawovsky AJ, Chory J. The geminivirus NSP acts as virulence factor to suppress an innate transmembrane receptor kinase-mediated defense signaling. Genes Dev. 2004;18:2545-56.

17. Feng $L$, Gao ZR, Xiao GQ, Huang RF, Zhang HW. Leucine rich repeat receptor-like kinase FON1 regulates drought stress and seed germination by activating the expression of ABA responsive genes in Rice. Plant Mol Biol Report. 2014;32:6.

18. Wu F, Sheng P, Tan J, Chen X, Lu G, Ma W, Heng Y, Lin Q, Zhu S, Wang J, Wang J, Guo X, Zhang X, Lei C, Wan J. Plasma membrane receptor-like kinase leaf panicle 2 acts downstream of the drought and salt tolerance transcription factor to regulate drought sensitivity in rice. J Exp Bot. 2015;66: 271-81

19. Lim CW, Yang SH, Shin KH, Lee SC, Kim SH. The AtLRK10L1.2, Arabidopsis, ortholog of wheat LRK10, is involved in ABA-mediated signaling and drought resistance. Plant Cell Rep. 2015;34:447-55.

20. Ouyang SQ, Liu YF, Liu P, Lei G, He SJ, Ma B, Zhang WK, Zhang JS, Chen SY. Receptor-like kinase OsSIK1 improves drought and salt stress tolerance in rice (Oryza sativa) plants. Plant J. 2010;62:316-29.

21. Chen LJ, Wuriyanghan H, Zhang YQ, Duan KX, Chen HW, Li QT, Lu X, He SJ, Ma B, Zhang WK, Lin Q, Chen SY, Zhang JS. An S-domain receptor-like kinase, OsSIK2, confers abiotic stress tolerance and delays dark-induced leaf senescence in rice. Plant Physiol. 2013;163:1752-65.

22. Fàbregas N, Lozano-Elena F, Blasco-Escámez D, Tohge T, Martínez-Andújar C, Albacete A, Osorio S, Bustamante M, Riechmann JL, Nomura T, Yokota T, Conesa A, Alfocea FP, Fernie AR, Caño-Delgado Al. Overexpression of the vascular brassinosteroid receptor BRL3 confers drought resistance without penalizing plant growth. Nat Commun. 2018;9:4680.

23. Castells E, Casacuberta JM. Signalling through kinase-defective domains: the prevalence of atypical receptor-like kinases in plants. J Exp Bot. 2007;58: 3503-11.

24. Langeberg LK, Scott JD. Signalling scaffolds and local organization of cellular behaviour. Nat Rev Mol Cell Biol. 2015;16:232-44.

25. Kung JE, Jura N. Structural basis for the non-catalytic functions of protein kinases. Structure. 2016;24:7-24

26. Sierla M, Hõrak H, Overmyer K, Waszczak C, Yarmolinsky D, Maierhofer T, Vainonen JP, Salojärvi J, Denessiouk K, Laanemets K, Tõldsepp K, Vahisalu T, Gauthier A, Puukko T, Paulin L, Auvinen P, Geiger D, Hedrich R, Kollist H, Kangasjärvi J. The receptor-like pseudokinase GHR1 is required for stomatal closure. Plant Cell. 2018;30:2813-37.

27. Zhang H, Zhu Q, Cui J, Wang Y, Chen MJ, Guo X, Tagliabracci VS, Dixon JE, Xiao J. Structure and evolution of the Fam20 kinases. Nat Commun. 2018;9: 1218.

28. Lecointre C, Simon V, Kerneur C, Allemand F, Fournet A, Montarras I, Pons JL, Gelin M, Brignatz C, Urbach S, Labesse G, Roche S. Dimerization of the Pragmin pseudo-kinase regulates protein tyrosine phosphorylation. Structure. 2018;26:545-54.

29. Blaum BS, Mazzotta S, Noldeke ER, Halter T, Madlung J, Kemmerling B, Stehle T. Structure of the pseudokinase domain of BIR2, a regulator of BAK1-mediated immune signaling in Arabidopsis. J Struct Biol. 2014;186: $112-21$

30. Halter T, Imkampe J, Mazzotta S, Wierzba M, Postel S, Bücherl C, Kiefer C, Stahl M, Chinchilla D, Wang X, Nürnberger T, Zipfel C, Clouse S, Borst JW, Boeren S, de Vries SC, Tax F, Kemmerling B. The Leucine-rich repeat receptor kinase BIR2 is a negative regulator of BAK1 in plant immunity. Curr Biol. 2014;24:134-43.

31. Somssich M, Ma Q, Weidtkamp-Peters S, Stahl Y, Felekyan S, Bleckmann A, Seidel CAM, Simon R. Real-time dynamics of peptide ligand-dependent receptor complex formation in planta. Sci Signal. 2015;8:ra76.

32. Somssich M, Bleckmann A, Simon R. Shared and distinct functions of the pseudokinase CORYNE (CRN) in shoot and root stem cell maintenance of Arabidopsis. J Exp Bot. 2016;67:4901-15.

33. Kumar D, Kumar R, Baek D, Hyun TK, Chung WS, Yun DJ, Kim JY. Arabidopsis thaliana RECEPTOR DEAD KINASE 1 functions as a positive regulator in plant responses to ABA. Mol Plant. 2017;10:223-43.

34. Zhang $X$, Facette $M$, Humphries JA, Shen Z, Park Y, Sutimantanapi D, Sylvester AW, Briggs SP, Smith LG. Identification of PAN2 by quantitative proteomics as a leucine-rich repeat-receptor-like kinase acting upstream of PAN1 to polarize cell division in maize. Plant Cell. 2012;24:4577-89.

35. Hua D, Wang C, He J, Liao H, Duan Y, Zhu Z, Guo Y, Chen Z, Gong Z. A plasma membrane receptor kinase, GHR1, mediates abscisic acid- and hydrogen peroxide-regulated stomatal movement in Arabidopsis. Plant Cell. 2012;24:2546-61.

36. Gish LA, Clark SE. The RLK/Pelle family of kinases. Plant J. 2011;66:117-27.

37. Greeff C, Roux M, Mundy J, Petersen M. Receptor like kinase complexes in plant innate immunity. Front Plant Sci. 2012;3:209.

38. Bi G, Liebrand TWH, Bye RR, Postma J, van der Burgh AM, Robatzek S, Xu X Joosten MHAJ. SOBIR1 requires the GXXxG dimerization motif in its transmembrane domain to form constitutive complexes with receptor-like proteins. Mol Plant Pathol. 2016;17:96-107.

39. van der Burgh AM, Postma J, Robatzek S, Joosten MHAJ. Kinase activity of SOBIR and BAK1 is required for immune signalling. Mol Plant Pathol. 2019; 20:410-22.

40. Zheng J, Fu J, Gou M, Huai J, Liu Y, Jian M, Huang Q, Guo X, Dong Z, Wang $H$, Wang G. Genome-wide transcriptome analysis of two maize inbred lines under drought stress. Plant Mol Biol. 2010;72:407-21.

41. Hruz T, Laule O, Szabo G, Wessendorp F, Bleuler S, Oertle L, Widmayer P, Gruissem W, Zimmermann P. Genevestigator V3: a reference expression database for the meta-analysis of transcriptomes. Adv Bioinforma. 2008; 2008:420747.

42. Guimarães CRW, Rai BK, Munchhof MJ, Liu S, Wang J, Bhattacharya SK, Buckbinder L. Understanding the impact of the P-loop conformation on kinase selectivity. J Chem Inf Model. 2011;51:1199-204.

43. Eyers PA, Murphy JM. Dawn of the dead: protein pseudokinases signal new adventures in cell biology. Biochem Soc Trans. 2013;4:969-74.

44. Fukuda K, Knight JDR, Piszczek G, Kothary R, Qin J. Biochemical, proteomic, structural, and thermodynamic characterizations of integrinlinked kinase (ILK): cross-validation of the pseudokinase. J Biol Chem. 2011:286:21886-95.

45. Jura N, Shan Y, Cao X, Shaw DE, Kuriyan J. Structural analysis of the catalytically inactive kinase domain of the human EGF receptor 3. Proc Natl Acad Sci U S A. 2009;106:21608-13.

46. Grutter C, Sreeramulu S, Sessa G, Rauh D. Structural characterization of the RLCK family member BSK8: a pseudokinase with an unprecedented architecture. J Mol Biol. 2013:425:4455-67.

47. Zeqiraj E, Filippi BM, Deak M, Alessi DR, van Aalten DMF. Structure of the LKB1-STRAD-MO25 complex reveals an allosteric mechanism of kinase activation. Science. 2009;326:1707-11.

48. Reese ML, Boothroyd JC. A conserved non-canonical motif in the pseudoactive site of the ROP5 pseudokinase domain mediates its effect on toxoplasma virulence. J Biol Chem. 2011;286:29366-75.

49. Bendova-Biedermannova L, Hobza J, Vondrasek J. Identifying key residues in proteins using inter-residue interaction energy matrix. Proteins. 2008;72:40213.

50. Zhang L, Li X, Li D, Sun Y, Li Y, Luo Q, Liu Z, Wang J, Li X, Zhang H, Lou Z, Yang Y. CARK1 mediates ABA signaling by phosphorylation of ABA receptors. Cell Discov. 2018;4:30.

51. Cartwright HN, Humphries JA, Smith LG. PAN1: a receptor-like protein that promotes polarization of an asymmetric cell division in maize. Science. 2009:323:649-51.

52. Sutimantanapi D, Pater D, Smith LG. Divergent roles for maize PAN1 and PAN2 receptor-like proteins in cytokinesis and cell morphogenesis. Plant Physiol. 2014;164:1905-17.

53. Facette MR, Park Y, Sutimantanapi D, Luo A, Cartwright HN, Yang B, Bennett EJ, Sylvester AW, Smith LG. The SCAR/WAVE complex polarizes PAN receptors and promotes division asymmetry in maize. Nat Plants. 2015;1: 14024.

54. Lewis JD, Lee AH, Hassan JA, Wan J, Hurley B, Jhingree JR, Wang PW, Lo T, Youn JY, Guttman DS, Desveaux D. The Arabidopsis ZED1 pseudokinase is required for ZAR1-mediated immunity induced by the Pseudomonas syringae type III effector HopZ1a. Proc Natl Acad Sci U S A. 2013;110:18722-7.

55. Panchy N, Lehti-Shiu M, Shiu SH. Evolution of gene duplication in plants. Plant Physiol. 2016;171:2294-316.

56. Eyers PA, Murphy JM. The evolving world of pseudoenzymes: proteins, prejudice and zombies. BMC Biol. 2016;14:98.

57. Wu Y, Xun Q, Guo Y, Zhang J, Cheng K, Shi T, He K, Hou S, Gou X, Li J. Genome-wide expression pattern analyses of the Arabidopsis leucine-rich repeat receptor-like kinases. Mol Plant. 2016;9:289-300.

58. Wang $T$, Liang L, Xue Y, Jia PF, Chen W, Zhang MX, Wang YC, Li HJ, Yang WC. A receptor heteromer mediates the male perception of female attractants in plants. Nature. 2016;531:241-4. 
59. Xi L, Wu XN, Gilbert M, Schulze WX. Classification and interactions of LRR receptors and co-receptors within the Arabidopsis plasma membrane - an overview. Front Plant Sci. 2019;10:472.

60. Jones MA, Raymond MJ, Smirnoff N. Analysis of the root-hair morphogenesis transcriptome reveals the molecular identity of six genes with roles in root-hair development in Arabidopsis. Plant J. 2006;45:83-100.

61. Sklodowski K, Riedelsberger J, Raddatz N, Riadi G, Caballero J, Chérel I, Schulze W, Graf A, Dreyer I. The receptor-like pseudokinase MRH1 interacts with the voltage-gated potassium channel AKT2. Sci Rep. 2017;7:44611.

62. Hammarén HM, Virtanen AT, Silvennoinen O. Nucleotide-binding mechanisms in pseudokinase. Biosci Rep. 2015;36:e00282.

63. Xu SL, Rahman A, Baskin TI, Kieber JJ. Two leucine-rich repeat receptor kinases mediate signaling, linking cell wall biosynthesis and ACC synthase in Arabidopsis. Plant Cell. 2008;20:3065-79.

64. Kwak SH, Shen R, Schiefelbein J. Positional signaling mediated by a receptor-like kinase in Arabidopsis. Science. 2005;307:1111-3.

65. Shao HB, Chu LY, Jaleel CA, Zhao CX. Water-deficit stress-induced anatomical changes in higher plants. C R Biol. 2008;331:215-25.

66. Tardieu F. Any trait or trait-related allele can confer drought tolerance: just design the right drought scenario. J Exp Bot. 2012;63:25-31.

67. Savitsky P, Bray J, Cooper CDO, Marsden BD, Mahajan P, Burgess-Brown NA, Gileadi $\mathrm{O}$. High-throughput production of human proteins for crystallization: the SGC experience. J Struct Biol. 2010;172:3-13.

68. Edelhock H. Spectroscopic determination of tryptophan and tyrosine in proteins. Biochemistry. 1987;6:1948-54.

69. Zhao H, Piszczek G, Schuck P. SEDPHAT - a platform for global ITC analysis and global multimethod analysis of molecular interactions. Methods. 2015; 76:137-48.

70. Kabsch W. XDS. Acta Crystallogr D Biol Crystallogr. 2010;66(Pt 2):125-32.

71. Winn MD, Ballard CC, Cowtan KD, Dodson EJ, Emsley P, Evans PR, Keegan RM, Krissinel EB, Leslie AG, McCoy A, McNicholas SJ, Murshudov GN, Pannu NS, Potterton EA, Powell HR, Read RJ, Vagin A, Wilson KS. Overview of the CCP4 suite and current developments. Acta Crystallogr D Biol Crystallogr. 2011;67(Pt 4):235-42.

72. McCoy AJ, Grosse-Kunstleve RW, Adams PD, Winn MD, Storoni LC, Read RJ Phaser crystallographic software. J Appl Crystallogr. 2007:40(Pt 4):658-74.

73. Aquino B, Couñago RM, Verza N, Ferreira LM, Massirer KB, Gileadi O, Arruda P. Structural characterization of maize SIRK1 kinase domain reveals an unusual architecture of the activation segment. Front Plant Sci. 2017:8:852.

74. Emsley P, Lohkamp B, Scott WG, Cowtan K. Features and development of coot. Acta Crystallogr D Biol Crystallogr. 2010;66(Pt 4):486-501.

75. Chen VB, Arendall WB 3rd, Headd JJ, Keedy DA, Immormino RM, Kapral GJ Murray LW, Richardson JS, Richardson DC. MolProbity: all-atom structure validation for macromolecular crystallography. Acta Crystallogr D Biol Crystallogr. 2010;66(Pt 1):12-21.

76. Maize Genetics and Genomics Database. https://www.maizegdb.org/. Accessed 18 June 2018.

77. Phytozome12 Database. https://phytozome.jgi.doe.gov/pz/portal.html. Accessed 18 June 2018.

78. PLAZA 4.0 Database. https://bioinformatics.psb.ugent.be/plaza/. Accessed 18 June 2018.

79. The Arabidopsis Information Resource (TAIR). https://www.arabidopsis.org/. Accessed 18 June 2018.

80. EnsemblPlants Database. http://plants.ensembl.org/index.html. Accessed 18 June 2018.

81. National Center for Biotechnology Information (NCBI) Database. https:// www.ncbi.nlm.nih.gov/. Accessed 18 June 2018.

82. Zheng $Y$, Jiao C, Sun H, Rosli HG, Pombo MA, Zhang P, Banf M, Dai X, Martin GB, Giovannoni JJ, Zhao PX, Rhee SY, Fei Z. iTAK: a program for genome-wide prediction and classification of plant transcription factors, transcriptional regulators, and protein kinases. Mol Plant. 2016;9:1667-70.

83. Gribskov M, Fana F, Harper J, Hope DA, Harmon AC, Smith DW, Tax FE, Zhang G. PlantsP: a functional genomics database for plant phosphorylation. Nucleic Acids Res. 2001;29:111-3.

84. Thompson JD, Gibson T, Higgins DG. Multiple sequence alignment using ClustalW and ClustalX. Curr Protoc Bioinformatics. 2003;1:2-3.

85. Tamura K, Stecher G, Peterson D, Filipski A, Kumar S. MEGA6: molecular evolutionary genetics analysis version 6.0. Mol Biol Evol. 2013;30:2725-9.

86. Saitou N, Nei M. The neighbor-joining method: a new method for reconstructing phylogenetic trees. Mol Biol Evol. 1987;4:406-25.
87. Zuckerkandl E, Pauling L. Evolutionary divergence and convergence in proteins. In: Bryson V, Vogel HJ, editors. Evolving genes and proteins. New York: Academic Press; 1965. p. 97-166.

88. Hecht V, Vielle-Calzada JP, Hartog MV, Schmidt EDL, Boutilier K, Grossniklaus U, de Vries SC. The Arabidopsis SOMATIC EMBRYOGENESIS RECEPTOR KINASE 1 gene is expressed in developing ovules and embryos and enhances embryogenic competence in culture. Plant Physiol. 2001;127:80316.

89. Friedrichsen DM, Joazeiro CA, Li J, Hunter T, Chory J. Brassinosteroidinsensitive-1 is a ubiquitously expressed leucine-rich repeat receptor serine/ threonine kinase. Plant Physiol. 2000;123:1247-56.

90. Clark SE, Williams RW, Meyerowitz EM. The CLAVATA1 gene encodes a putative receptor kinase that controls shoot and floral meristem size in Arabidopsis. Cell. 1997;89:575-85.

91. Lehti-Shiu MD, Shiu SH. Diversity, classification and function of the plant protein kinase superfamily. Philos Trans R Soc Lond Ser B Biol Sci. 2012;367: 2619-39.

\section{Publisher's Note}

Springer Nature remains neutral with regard to jurisdictional claims in published maps and institutional affiliations.

Ready to submit your research? Choose BMC and benefit from:

- fast, convenient online submission

- thorough peer review by experienced researchers in your field

- rapid publication on acceptance

- support for research data, including large and complex data types

- gold Open Access which fosters wider collaboration and increased citations

- maximum visibility for your research: over $100 \mathrm{M}$ website views per year

At $\mathrm{BMC}$, research is always in progress.

Learn more biomedcentral.com/submissions 